Hydrology and Earth System Sciences, 8(3), 589-595 (2004) C EGU

\title{
Sustainability of UK forestry: contemporary issues for the protection of freshwaters, a conclusion
}

\author{
C. Neal ${ }^{1}$, S.J. Ormerod ${ }^{2}$, S.J. Langan ${ }^{3}$, T.R. Nisbet ${ }^{4}$ and J. Roberts ${ }^{1}$ \\ ${ }^{1}$ Centre for Ecology and Hydrology, Crowmarsh Gifford, Wallingford, OXON, OX10 8BB, UK \\ ${ }^{2}$ Catchment Research Group, Cardiff School of Biosciences, Cardiff University, P.O. Box 915, Cardiff, CF10 3TL, UK \\ ${ }^{3}$ Macaulay Institute, Craigiebuckler, Aberdeen, AB15 8QH, UK \\ ${ }^{4}$ Forest Research, Environmental Research Branch, Alice Holt Lodge, Farnham, Surrey, GU10 4LHE, UK \\ Email for corresponding author: cn@ceh.ac.uk
}

\begin{abstract}
This paper closes the Special Issue of Hydrology and Earth System Sciences entitled "Sustainability of UK forestry: contemporary issues for the protection of freshwaters" by presenting conclusions from the contributions together with associated research findings. The volume deals largely with issues of upland water quality and biology in the context of environmental research and management. The studies are linked to an array of issues which affect the sustainability of UK forestry in the context of the protection of freshwaters, freshwater ecosystems and freshwater organisms. These issues include atmospheric and climate driven factors (acidification from atmospheric pollutants, critical loads, climate-change and climate variability), forestry practice and hydrobiogeochemical processing both within-catchments and within-rivers. The findings lie within the context of the science and relate to environmental management.
\end{abstract}

Keywords: water quality, forestry, stream ecology, acidification, critical loads, nutrients

\section{Introduction}

Over the last century, the UK's need for secure and sustainable timber resources led to expansion in plantation forestry largely in the UK uplands in areas which are often economically marginal but, may nevertheless, be of considerable aesthetic and amenity value as well as being environmentally vulnerable. The expansion was driven by socio-economic factors linked to issues such as the maintenance and improvement of rural and other economies as well as the political requirement for strategic and secure supplies of home grown timber resources; the vital necessity for these was demonstrated the nation's vulnerability in two World Wars (Farmer and Nisbet, 2004). The scientific input to forest development has grown increasingly since the 1950 s, starting with the case of water resources. McCulloch and Robinson (1993) reviewed the early years of forest hydrological research and recorded the development of research catchments in the UK. More recently, research in the UK at the catchment scale has evolved through the environmental-issues of the 1960s, 70s and 80s (Hudson et $a l ., 1997 a)$. Forestry has been challenged and has often been criticised unfairly in relation to issues of water resources and environmental pollution, the latter being predominantly related to issues of nutrients, acidification and sediment. Forestry policy and scientific research have co-evolved, originally with some disharmony and always without the benefit of hindsight: common and laudable goals are now starting to coalesce. Forestry enterprises and the goals of forest management now emphasise the need for sustainable development as well as for forests to make a positive contribution to the maintenance and improvement of an ecologically healthy environment (Farmer and Nisbet, 2004). The protection of freshwaters is a key requirement of sustainable forestry and high priority has been given to the development of guidelines for best practice.

In this Special Issue, sustainability has been addressed in research papers on freshwater systems, mainly in the UK uplands (Neal et al., 2004a), where the soils are generally acidic and acid sensitive and many plantation forests are progressing through the first or second generation of rotation with harvesting and replanting. There may well be issues for lowland forestry, for example in relation to water stress, 
groundwater resources and the atmospheric pollution scavenging by a mosaic of small plantations across a landscape (Harding et al., 1992a,b; Neal, 2002; Neal et al., 1993). However, such lowland issues lie outwith the scope of the present study.

For the uplands, important issues for forestry in relation to water resources and sediment dynamics have been considered although some issues may well remain (Farmer and Nisbet, 2004). However, the hydrological and sedimentological aspects have, largely, been resolved in earlier publications (Robinson et al., 2000; Hudson et al., 1997b; Leeks and Marks, 1997; Marks and Rutt, 1997); except in relation to management of riparian forests (Broadmeadow and Nisbet, 2004), they are not dealt with here. Sadly, difficulties still remain in finalising the water balances for the Plynlimon catchments in mid-Wales, although they are a benchmark for UK hydrological experimentation and research. These difficulties concern reliable estimates of precipitation (including mist) over forests, (Hudson et al., 1997b; Robinson et al., 2004). Yet two papers are indicative of a revitalisation in hydrological research by integrating the research findings for the Plynlimon catchments within a GIS framework (Brandt et al., 2004) and developing the hydrogeological sciences in connection with fracture flow movement of water through catchments (Haria and Shand, 2004).

\section{Water quality}

In response to both climate-driven and within-catchment factors, the water quality of the UK uplands is changing in both moorland and forested ecosystems (Langan and Hirst, 2004; Neal et al., 2004d; Ness et al., 2004; Reynolds et al., 2004). Recent reductions in acidic deposition from $\mathrm{SO}_{\mathrm{x}}$ and non-marine $\mathrm{SO}_{4}\left(\mathrm{SO}_{4}^{*}\right)$ have led to a decline in acidic runoff and in $\mathrm{SO}_{4}{ }^{*}$ concentrations in the streams. However, other more quasi-cyclical changes may derive from climate variability linked to the North Atlantic Oscillation (NAO). The NAO affects components such as dissolved organic carbon, nitrate, sea salts ( $\mathrm{Na}$ and $\mathrm{Cl}$ in particular) and, perhaps, trace metals (Neal et al., 1996; Robson and Neal, 1996; Evans et al., 2001; Ness et al., 2004), as well as dissolved organic carbon (Reynolds et al., 2004; Neal et al., 2004e). The relative effects of climate change on the forcing and amplification of the NAO are still unclear but linked water quality changes may well be of considerable significance if current trends continue. At the very least, they illustrate a clear climatic signal that can confound, compound or mask trends due to other more local catchmentscale effects.

A major area of water quality research has involved the development and assessment of 'critical loads' to determine at what level of pollutant deposition the biological effect in woodland ecosystems and streams will be influenced. This provides a yardstick to set alongside environmental management strategies. Studies of critical loads by Langan et al. (2004) point out that, while negative impacts of acidic deposition on UK woodland habitats have yet to be reported, projected emissions reductions, if not maintained, might compromise the long-term sustainability of large areas of UK woodland. Bridcut et al. (2004) show that care must be taken in evaluating critical loads because of stress to fish caused by low acid neutralisation capacity events and the harmful effects on fish of $\mathrm{Al}$ due to complexation with dissolved organic carbon. Atmospheric deposition of both $\mathrm{S}$ and $\mathrm{N}$ is important not only in relation to river water quality and aquatic health but also in connection with tree growth, seedling germination and growth and soil and soil-water quality. Studies by Sheppard et al. (2004) based on dosing experiments for a young Sitka Spruce stand on acid peat soil showed that these trees are able to buffer the low nutrient levels and produce new growthonly if there is sufficient $\mathrm{N}$. Inputs of almost $100 \mathrm{~kg}-\mathrm{N} \mathrm{ha}{ }^{-1} \mathrm{yr}^{-1}$ in addition to ambient $\mathrm{N}$ resulted in elevated foliar $\mathrm{N}$ and $\mathrm{N}_{2} \mathrm{O}$ losses and increased soil water $\mathrm{N}$, but did not reduce stem area growth. In a dosing experiment by Stutter et al. (2004), the effects of $\mathrm{H}_{2} \mathrm{SO}_{4}$, $\left(\mathrm{NH}_{4}\right)_{2} \mathrm{SO}_{4}$ and reduced $\mathrm{N}$ deposition on soil water quality was linked to chemical and physical growth indicators for pine seedlings. The results depend strongly upon the type of soil. For $\mathrm{H}_{2} \mathrm{SO}_{4}$ additions, different soil types responded similarly to decreased $\mathrm{pH}$ but differently to reduced $\mathrm{N}$. In microcosms of calc-silicate soils, nitrification of $\mathrm{NH}_{4}$ resulted in lower $\mathrm{pH}$ and higher cation leaching than in acid treatments. For quartzite and granitic soils, addition of $\left(\mathrm{NH}_{4}\right)_{2} \mathrm{SO}_{4}$ promoted cation leaching, although $\mathrm{pH}$ increased. Thus, soil type is important in respect of $\mathrm{N}$ and this affects biogeochemical cycling. While it might be predicted that $\mathrm{N}$ availability is important for seedling germination and development on quartz and granitic soils, it is a lack of sufficient $P$, the limiting nutrient, which may curtail growth.

What has not been resolved in regard to critical loads is the position of trace metals. This, in part, results from a lack of detailed information on inputs to catchments. However, studies at Plynlimon demonstrate the importance of metal deposition for trace metals of environmental concern such as $\mathrm{Cr}$ and Zn (Wilkinson et al., 1997; Neal et al., 1997a; Robson and Neal, 1996). Similarly in Scotland, Heal (2001) has indicated that increased Mn concentrations occur in surface waters in conifer forested catchments and that, following harvesting, further increases may occur. Grieve and Marsden (2001), from a study of comparable 
moorland and forest, showed that, despite considerable temporal and spatial variability, TOC, aluminium and Fe concentrations were 1.5 times higher in streams draining forested catchments.

An important issue for forestry is the effect of harvesting on stream water quality; the potential release of $\mathrm{NO}_{3}$ may increase the acidity and trace metal content of runoff. There is a huge body of research in this area. While, following felling, there is almost universally an increase in stream nitrate concentrations, there is most often little response with respect to the components of critical environmental concern - acidity, Al and trace metals (Neal et al., 2004b,c,d; Neal, 2004). At a localised scale, there may be some effects but, at the catchment scale, the impacts are masked by the natural variability within the climate-driven component of the catchment system. This is consistent with the current UK policy of phased felling of catchment areas, so that any localised change is diluted by unfelled parts of the catchment or by the recovery following replanting. One of the most surprising findings of the studies of felling on stream water quality has been the very small effect for poorly drained gley soils which (a) are highly acidic and (b) have the greatest potential from acidic runoff due to the impermeable nature of the catchments (Neal et al., 2004c). For the gley catchments, phosphate can be released to the soil water and, thence, to the stream. However, in the phosphorus-limiting conditions prevalent in most of the uplands, the release of phosphate is taken up rapidly by the biota and this may even lead to the loss of the nitrate signal in the stream that would naturally be expected following felling (Neal et al., 1998a,b, 2004c). All of this is extremely good news for present day UK forestry management practices except for the fact that Fe seems to be increasing in concentration in the Plynlimon forested catchments (Neal et al., 2004d,e).

The proposed major shift in the management of half of the Forestry Commission estate in Wales from patch to Continuous Cover Forestry reflects pressure for the sustainable development of multi-purpose forestry in which environmental, recreational, aesthetic and other considerations are as important as timber production (Reynolds, 2004). Potentially, this could be good news if the lessons learned from water quality and other studies were adopted into practice. Indeed, there are opportunities for reducing the scale of clear felling, increasing in some instances the phases of felling, increasing species diversity, changing the structure of plantation forests and maintaining uninterrupted woodland cover (Neal et al., 1998a,b; Neal and Reynolds, 1999; Reynolds, 2004). Whitehead et al. (2004) has considered issues of both upland and lowland afforestation on river water quality.

Long-term changes in water quality associated with forest rotation cycles raise issues of sustainability in consequence of acidification of the soil. This potential acidification results from base cation $(\mathrm{Ca}$ and $\mathrm{Mg}$ ) depletion of the soil store by uptake into the growing forest biomass and export from the catchment when the trees are harvested. Miller et al.,(1993) suggested that nutrient removal from sites will vary according to the type of harvesting: stem-only removes fewer elements than whole-tree harvesting. Unfortunately, there has been no such contribution to this volume by any modelling group although there was encouragement to do so. Field measurements do not indicate any significant uptake from the soil by the trees during their development, the results being within the measurement uncertainty of flux estimation (Reynolds and Stevens, 1998). Also, it is not clear that the trees will take base cations from the topsoil rather than from lower down the soil profile where weathering reactions dominate and where base cations are supplied by this weathering. When uptake of base cations from weathering sources by the biomass is dominant, there will be no significant soil acidification and indeed there may even be partial reduction of soil acidification by cycling of base cations from the weathering zone to the soil surface via the tree. Indeed, in a major report on the impacts of harvesting on stream acidification, Neal and Reynolds (1999) declined to apply long-term models to assess what may or may not happen. The issue remains open, with a need for balance and objectivity currently missing from some modelling predictions.

\section{Biology}

Plantation forests of exotic species bring not only changes to deposition chemistry, soils, and runoff character, but they also affect organisms. Because non-native forests occupy over $10 \%$ of Britain, the resulting ecological changes are cumulatively extensive, particularly in upland locations where planting has been concentrated. Although often colonised by native plants and animals, extensive forests have been criticised by conservationists because of the habitats that had been replaced (Peterken, 2001). Increasingly, however, forests world-wide are being viewed as a major opportunity to manage large areas for their environmental value - at least providing that appropriate improvements in forest design or management can deliver desirable elements with little reduction in fibre production and with demonstrable benefits relative to costs (Kerr, 1999; Hartley, 2002). Indeed, the UK forest industry, at least in the government sector, is bound by a range of international agreements to conserve biodiversity on its land holdings; in turn, the protection of biodiversity has become a key indicator of sustainable forest management (Moffat, 2002). 
Fulfilling such agreements depends on the ability of managers to understand the processes through which forests cause ecological change, and to translate this understanding into positive management action. Moreover, such management applies not only to habitats occupied directly by forest, but also to those biodiversity-rich habitats that are adjacent or downstream — such as rivers.

Interactions between British forests and rivers offer some of the best examples in the world of how such ecological effects have been recognised initially, then researched and translated into positive management. The research patterns followed in the UK have provided a benchmark for developments elsewhere - such as Ireland - where echoes of the situation in Britain have been combined with new lessons (Giller and O'Halloran, 2004). Over the last 20 years, information has grown about the physical, chemical and energy effects of forests particularly on upland British streams. They arise, for example through altered hydrology, acidification and alterations in allochthonous litter quality (Ormerod et al., 1987). To try to offset potentially negative effects, both on general riverine biodiversity and on priority species such as Atlantic Salmon Salmo salar, guidelines for riparian management have been developed and updated almost in tandem with available knowledge (Broadmeadow and Nisbet, 2004). Although some issues, such as acidification, are still difficult to resolve, 'riparian buffer strips' offer potentially important methods to reduce other risks, for example those of erosion, over-shading and loss of habitat heterogeneity along forest streams. The current second rotation of plantation forestry in Britain offers an unparalleled opportunity for further development and implementation of buffer strips. It is important, nevertheless, to continue to fill knowledge gaps about their role and ecological function and, hence, to optimise their design and long-term management. The majority of the biologicallyoriented contributions in this special issue focus on this aspect.

The riparian zone can be a major source of energy to upland streams in the form of leaf litter or terrestrial invertebrates, and several contributors in this special issue take up this theme. In two contributions, Pretty and Dobson (2004a, b) show not only how aquatic animal densities are increased by inputs of broadleaf litter; they also reaffirm that this effect depends on litter being retained within reaches. Both the form of leaves and the form of the channel are important in this regard: in channels, broadleaves are retained more effectively than conifers, while the presence of woody debris is crucial in providing retentive habitat structures. This is not yet fully recognised either in forest management guidelines or in stream channel management. Broadleaves are also important in delivering energy to streams in the form of terrestrial invertebrates, used in turn by vertebrate predators such as brown trout (Ormerod et al. 2004). While stream-dwelling trout are often flexible enough as predators to overcome the effects of food scarcity even in unproductive waters, terrestrial invertebrate prey almost certainly increases foraging opportunities. Perhaps most important of all, the overall energy subsidy provided in all forms from native riparian vegetation offers a means of enhancing secondary production in streams that would otherwise be unproductive - for example those that are acidified or still recovering. Broadleaf energy inputs are more beneficial in this respect, not only in comparison with exotic conifers but also in comparison to the native Pinus sylvestris (Collen et al. 2004).

Energy flow across the ecotone between streams and the riparian zone is not unidirectional, but also reflects export from the stream, e.g. in the form of emerging insects that provide prey for a wide array of riparian predators. River ecologists have recently begun to realise that the terrestrial adult phase of aquatic insects forms a crucial but poorly understood part of their life cycles. Activities such as feeding, mating, oviposition and dispersal can all involve interactions with riparian or even catchment vegetation, but few authors have examined how such activities might be affected by forestry (Briers et al. 2002; Petersen et al. in press). Briers and Gee (2004) review the available information and suggest that, while current forest management guidelines are probably beneficial to aquatic insects in their aerial and terrestrial phases, additional research is still required. Malcolm et al. (2004) clearly indicate variability in temperature and light regime for shaded and unshaded streams in moorland and forested terrains in the Cairngorms and this, in part, will influence biology. This variability changes according to local conditions and there is much heterogeneity, even for critical components such as acid neutralisation capacity, with heterogeneity increasing at finer and finer scales (Neal et al., 1997b, 1998a,b; Reynolds et al., 2001).

Some of the most intractable biological problems associated with conifer forestry in Britain, at least in acidsensitive areas, have been those arising from acidification (Ormerod et al. 1989). In these areas, low $\mathrm{pH}$ and accompanying metal concentrations cause major limits to the richness and abundance of stream organisms, and effects are likely to continue for decades to come in spite of the recent trends towards recovery. Irrespective of the role of plantation forests in exacerbating the problem, the association between the location of forests and acid waters means that acidification might offset some of the potential benefits that could otherwise arise from positive riparian management. It is intriguing that forest/acidification issues 
are less prominent than formerly as a research theme among stream ecologists. Only Bridcut et al. (2004) make this the explicit focus of biological studies in this volume: in contrast, major efforts still centre on acidification issues with respect to the water quality of the 'inorganics', as can be judged from the section on water quality presented above. Perhaps the answers, and the management choices, regarding acidification in forest streams are already clear: until recovery is substantial, widespread or accelerated by liming, the only option is to manage acidified streams to increase production or diversity among acid-sensitive organisms. In this respect, the Forest and Water Guidelines are positive. Moreover, the potential consequences of P release on stream water quality due to felling in a gley catchment at Plynlimon (Neal et al., 2004c) presumably stimulated biological activity ( $\mathrm{P}$ is probably the limiting nutrient in the uplands, Davison et al.,1995) and this $\mathrm{P}$ fertilisation reduced the acidity of acid deposition impacted lakes.

\section{Conclusion}

UK hydrochemical and biological research on forested ecosystems in connection with water quality issues has flourished over the past 20 or more years and, because of the contacts between research scientists and forestry practitioners, the findings have already been integrated into the environmental management of forests in the UK. This, for example, has clearly occurred in assessing and dealing with the impacts of conifer harvesting in upland areas on water quality (Neal and Reynolds, 1999); phased felling rather than clear felling suggests that the effects on water quality of timber harvesting might well be insignificant. Improvements in environmental management of forests rely not only on good science but also on the ability of scientists to explain, lucidly, what is needed in a straightforward and practical way. Also, the forestry fraternity are important in influencing the science through discourse on the actual issues rather than on those the scientist may believe are the vital issues..

In the spirit of this special issue, understanding and managing the links between forests and associated biological resources requires a multi-disciplinary view in which ecology, hydrology, hydrochemistry and fluvial geomorphology are strongly interfaced. Both in the specific papers, and in the overall theme of Hydrology and Earth System Sciences, this volume demonstrates just how effective the outcome of such inter-disciplinary collaboration can be. This does not mean that the research is complete. For example, the long-term monitoring programmes indicate a change in water quality that (a) has not been predicted and (b) is linked in a complex way to a number of factors (climate change and instability, pollution climate, the introduction of new technologies and forestry management options and socio-economic drivers, etc). Critical needs include:

- Continuing to measure change, to see what actually happens rather than what is just hoped, or expected, or predicted through modelling.

- Recognising that the environment is complex and heterogeneous with fractal processing and non-linear dynamics occurring with feedback mechanisms.

- Recognising that currently used environment impact models are simplifications which may be over simplifications both of the science and environmental management.

- Coupling the process- and measurement-based sciences with new and emerging modelling research to advance the next generation of environmental impact models.

- Assessing quantitatively whether repeated rotation cycles of forestry do or do not lead to acidification by base cation uptake into the growing biomass and export from the catchment on harvesting. This aspect is critical to the question of the environmental sustainability of forestry in the UK uplands.

- Putting more emphasis and resources on biological monitoring to align it to that made for water quality. This enables proper assessment of changes in both seasonal and annual frameworks.

- Combining water quality and biological studies within an integrated modelling framework. This lies within the spirit and requirements of the new and emerging EU framework directives to gauge impacts directly in terms of biology and ecology.

- Increasingly research work must include a focus on lowland forests, which will play a role in a wider set of environmental issues particularly in relation to restoration of formerly degraded environments such as intensively managed agricultural areas in riparian areas and, more generally, in flood plains. The potential drivers for this change will be improvement in water quality, wider habitat provision to increase biodiversity and flood alleviation under changing climates

- Recognising that, while science must be integrated with policy within an extended peer group setting (using the existing science within a technological framework), the science must be enquiry driven to produce the concepts and approaches that will lead to the next generation of environmental impact models. Balancing these two requirements is one of the most difficult areas of research funding today, tilted as it is towards technological application. 
Major inroads have been made to the integrated research on forests and water quality as this volume (Neal et al., 2004a) shows. The resulting advances have to be applauded.

\section{References}

Brandt, C., Robinson, M. and Finch, J.W., 2004. Anatomy of a catchment: the relation of physical attributes of the Plynlimon catchments to variations in hydrology and water status. Hydrol. Earth Syst. Sci., 8, 345-354.

Bridcut, E.E., McNish, J. and Harriman, R., 2004. Incorporating episodicity into estimates of Critical Loads for juvenile salmonids in Scottish streams. Hydrol. Earth Syst. Sci., 8, 366376.

Briers, R.A. and Gee, J.H.R., 2004. Riparian forestry management and adult stream insects. Hydrol. Earth Syst. Sci., 8, 545-549.

Briers, R. A., Cariss, H.M. and Gee, J. H. R., 2002. Dispersal of adult stoneflies (Plecoptera) from upland streams draining catchments with contrasting land-use. Arch. Hydrobiologie, 155, $627-644$.

Broadmeadow, S. and Nisbet, T.R., 2004. The effects of riparian forest management on the freshwater environment - a literature review of best practice management. Hydrol. Earth Syst. Sci., 8, 286-305.

Collen, P., Keay, E.J. and Morrison, B.R.S., 2004. Processing of pine (Pinus sylvestris) and birch (Betula pubescens) leaf material in a small river system in the northern region of the Cairngorm Mountain range, Scotland. Hydrol. Earth Syst. Sci. 8, 567-577.

Davison, W., George, D.G. and Edwards, N.J.A., 1995. Nature, 377, 504-507.

Evans, C.D., Monteith, D.T. and Harriman, R., 2001. Long-term variability in the deposition of marine ions at west coast sites in the UK Acid Waters Monitoring Network: impacts on surface water chemistry and significance for trend determination. Sci Total Envir., 265, 115-129.

Farmer, R.A. and Nisbet, T.R., 2004. An overview of forest management and change with respect to environmental protection in the UK. Hydrol. Earth Syst. Sci., 8, 279-285.

Giller, P. and O'Halloran, J., 2004. Forestry and the aquatic environment: studies from an Irish context. Hydrol. Earth Syst. Sci., 8, 314-326.

Grieve, I.C. and Marsden, R. 2001 Effects of forest cover and topographic factors on TOC and associated metals at various scales in western Scotland. Sci. Total Envir., 265, 142-152.

Hartley, M. J., 2002. Rationale and methods for conserving biodiversity in plantation forests. Forest Ecol. Manage., 155, 81-95.

Haria, A.H. and Shand, P., 2004. Evidence for deep sub-surface flow routing in forested upland Wales: Implications for contaminant transport and stream flow generation. Hydrol. Earth Syst. Sci., 8, 334-344.

Harding, R.J., Neal, C. and Whitehead, P.G., 1992a. Hydrological effects of plantation forestry in north-western Europe. In: Responses of forest ecosystems to environmental change, A. Teller, P. Mathy and J.N.R. Jeffers (Eds.), Elsevier, London. UK. 445-455.

Harding, R.J., Hall, R.L., Neal, C., Roberts, J.M., and Rosier, T.P.W., 1992b. Hydrological impacts of broadleaf woodlands: implications for water use and water quality. Project Report 115/03/ST: Environment Agency, Rivers House, Waterside Drive, Almondsbury, Bristol, BS12 2UD, UK. 207pp.

Heal, K.V., 2001. Manganese and land-use in upland catchments in Scotland. Sci. Total Envir., 265, 169-180.
Hudson, J.A., Gilman, K. and Calder, I.R., 1997a. Land use and water quality issues in the uplands with reference to the Plynlimon study. Hydrol. Earth Syst. Sci., 1, 389-398.

Hudson, J.A., Crane, S.B. and Blackie, J.R., 1997b. The Plynlimon water balance 1969-1995: The impact of forest and moorland vegetation on evaporation and streamflow in upland catchments. Hydrol. Earth Syst. Sci., 1, 409-428.

Kerr, G., 1999.The use of silvicultural systems to enhance the biological diversity of plantation forests in Britain. Forestry, 72, 191-205.

Langan, S.J. and Hirst, D., 2004. An analysis of the long-term variation in stream water quality for three upland catchments at Loch Dee (Galloway, SW Scotland) under contrasting land management. Hydrol. Earth Syst. Sci., 8, 422-435.

Langan, S.J., Hall, J., Reynolds, B., Broadmeadow, M., Hornung, M. and Cresser, M.S., 2004. The development of an approach to assess critical loads of acidity for woodland habitats in Great Britain. Hydrol. Earth Syst. Sci., 8, 355-365.

Leeks, G.J.L. and Marks, S.D., 1997. Dynamics of river sediments in forested headwater streams; Plynlimon. Hydrol. Earth Syst. Sci., 1, 483-497.

Malcolm, I.A., Hannah, D.M., Donaghy, M.J., Soulsby, C. and Youngson, A.F., 2004. The influence of riparian woodland on the spatial and temporal variability of stream water temperatures in an upland salmon stream. Hydrol. Earth Sys. Sci., 8, 449459.

Marks, S.D. and Rutt, G.P., 1997. Fluvial sediment inputs to upland gravel bed rivers. Hydrol. Earth Sys. Sci., 1, 499-508.

McCulloch, J.S.G and Robinson, M., 1993. History of forest hydrology. J. Hydrol, 150, 189-216.

Miller, J.D., Cooper, J. M. and Miller, H.G., 1993 A comparison of above-ground component weights and element amounts in four forest species at Kirkton Glen. J. Hydrol. 145, 419-438.

Moffat, A.J., 2002. The state of British forests at the beginning of the 21 st century. Int. Forestry Rev., 4, 171-183.

Neal, C., 2002. Interception and attenuation of atmospheric pollution in a lowland ash forested site, Old Pond Close, Northamptonshire, UK. Sci. Total Envir., 282/283, 99-109.

Neal, C., 2004. The water quality functioning of the upper River Severn, Plynlimon, mid Wales: issues of monitoring, process understanding and forestry. Hydrol. Earth Syst. Sci., 8, 521532.

Neal, C. and Reynolds, B., 1999. The impact of conifer harvesting and replanting on upland water quality. R\&D Technical report to the Environment Agency: Report P211. Environment Agency, Rivers House, Waterside Drive, Aztec West, Almondsbury, Bristol, BS32 4UD, UK. 137pp.

Neal, C., Robson, A.J., Bhardwaj, C.L., Conway, T., Jeffery, H.A., Neal, M., Ryland, G.P., Smith, C.J. and Walls, J., 1993. Relationships between precipitation, stemflow and throughfall for a low-land beech plantation, Black Wood, southern England: findings on interception at a forest edge and the effects of storm damage. J. Hydrol., 146, 221-233.

Neal, C., Smith, C.J., Jeffery, H.A., Harrow, M.L. and Neal, M. 1996. Dissolved chromium pollution in rainfall and surface waters in Mid-Wales during the mid 1980s. Sci. Total Envir., 188, 127-138.

Neal, C., Wilkinson, R.J., Neal, M., Harrow, M.L., Wickham, H., Hill, L. and Morfitt, C., 1997a. The hydrochemistry of the headwaters of the River Severn, Plynlimon, Wales. Hydrol. Earth Syst. Sci., 1, 583-618.

Neal, C., Hill, T., Hill, S. and Reynolds, B., 1997b. Acid neutralization capacity measurements in surface and ground waters in the Upper River Severn, Plynlimon: from hydrograph splitting to water flow pathways. Hydrol. Earth Syst. Sci., 1, 687-696. 
Neal, C., Reynolds, B., Adamson, J.K., Stevens, P.A., Neal, M., Harrow, M.L. and Hill, S., 1998a. Analysis of the impacts of major anion variations on surface water acidity: case studies from Wales and Northern England. Hydrol. Earth Syst. Sci., 2, 303-322.

Neal, C., Reynolds, B., Wilkinson, R.J., Hill, T., Neal, M., Hill, S., and Harrow, M.L., 1998b. The impacts of conifer harvesting on runoff water quality: a regional survey for Wales. Hydrol. Earth Syst. Sci., 2, 323-344.

Neal, C., Ormerod, S.J., Langan, S.J., Nisbet, T.R. and Roberts, J., 2004a. Sustainability of UK forestry: contemporary issues for the protection of freshwaters, an introduction. Hydrol. Earth Syst. Sci., 8, 277-278.

Neal, C., Reynolds, B., Neal, M. and Williams, B., 2004b. The hydrochemistry of plantation spruce forest catchments with brown earth soils, Vyrnwy in mid Wales. Hydrol. Earth Syst. Sci., 8, 460-484.

Neal, C., Reynolds, B., Neal, M., Wickham, H., Hill, L. and Williams, B., 2004c. The water quality of streams draining a plantation forest on gley soils: the Nant Tanllwyth, Plynlimon, mid-Wales. Hydrol. Earth Syst. Sci., 8, 485-502.

Neal, C., Reynolds, B., Neal, M., Wickham, H., Hill, L. and Williams, B., 2004d. The impact on conifer harvesting on stream water quality: the Afon Hafren, mid-Wales. Hydrol. Earth Syst. Sci., 8, 503-520.

Neal, C., Robson, A.J., Neal, M. and Reynolds, B., 2004e. Dissolved organic carbon for upland acidic and acid sensitive catchments in mid-Wales. J. Hydrol. (in press)

Ness, L., Neal, C., Davies, T.D. and Reynolds, B., 2004. Impacts of the North Atlantic oscillation on stream water chemistry in mid-Wales. Hydrol. Earth Syst. Sci., 8, 409-421.

Ormerod, S. J., Donald, A. P. and Brown, S. J., 1989. The influence of plantation forestry on the $\mathrm{pH}$ and aluminium concentration of upland Welsh streams: a re-examination. Environ. Pollut., 62, 47-62.

Ormerod, S.J., Mawle, G.W. and Edwards, R.W., 1987. The influence of forest on aquatic fauna. In: Environmental aspects of plantation forestry in Wales, J. E. Good (Ed.), I.T.E. symposium no. 22, Institute of Terrestrial Ecology, Grangeover-Sands, UK. 37-49.

Ormerod, S.J., Jones, M.E., Jones, M.C. and Phillips, D.R., 2004. The effects of riparian forestry on invertebrate drift and brown trout in upland streams of contrasting acidity. Hydrol. Earth Syst. Sci., 8, 578-588.

Peterken, G. F., 2001. Ecological effects of introduced tree species in Britain. Forest Ecol. Manage., 141, 31-42.

Petersen, I., Masters, Z., Hildrew, A. G. and Ormerod, S. J., 2004. Dispersal of adult aquatic insects in catchments of differing land use. J. Appl. Ecol., in press.
Pretty, J.L. and Dobson, M., 2004a. Leaf transport and retention in a high gradient stream. Hydrol. Earth Syst. Sci., 8, 550-559.

Pretty, J.L. and Dobson, M., 2004b. The response of macroinvertebrates to artificially enhanced detritus levels in plantation streams. Hydrol. Earth Syst. Sci., 8, 560-566.

Reynolds, B., 2004. Continuous Cover Forestry: Possible implications for surface water acidification in the UK uplands. Hydrol. Earth Syst. Sci., 8, 306-313.

Reynolds, B. and Stevens, P.A., 1998. Assessing soil calcium depletion following growth and harvesting of Sitka Spruce plantation forestry in the acid sensitive Welsh uplands. Hydrol. Earth Syst. Sci., 2, 345-352.

Reynolds, B., Neal, C. and Norris, D.A., 2001. Evaluation of regional acid sensitivity predictions using field data: issues of scale and heterogeneity. Hydrol. Earth Syst. Sci., 5, 75-81.

Reynolds, B., Stevens, P.A., Brittain, S.A., Norris, D.A., Hughes, S. and Wood, C., 2004. Long-term changes in precipitation and stream water chemistry in small forest and moorland catchments at Beddgelert Forest, north Wales. Hydrol. Earth Syst. Sci., 8, 436-448.

Robinson, M., Boardman, J. Evans, R. Heppell, K., Packman, J. and Leeks, G.J.L., 2000. Land use change. In: The Hydrology of the UK, a study of change, M. Acreman (Ed.), Routledge, London, UK. 30-54.

Robinson, M., Grant, S.J. and Hudson, J.A., 2004. Measuring rainfall to a forest canopy: assessments of the performance of canopy level rain gauges. Hydrol. Earth Syst. Sci., 8, 327-333.

Robson, A.J. and Neal, C. 1996. Water quality trends at an upland Welsh site. Hydrol. Process., 10, 183-203.

Sheppard, L.J., Crossley, A., Harvey, F.J., Skiba, U., Coward, P. and Ingleby, K., 2004. Effects of five years of frequent $\mathrm{N}$ additions, with or without acidity, on the growth and belowground dynamics of a young Sitka spruce stand growing on an acid peat: Implications for sustainability. Hydrol. Earth Syst. Sci., 8, 377-391.

Stutter, M.I., Alam, M.S., Langan, S.J., Woodin, S.J., Smart, R.P. and Cresser, M.S., 2004. The effects of $\mathrm{H}_{2} \mathrm{SO}_{4}$ and $\left(\mathrm{NH}_{4}\right)_{2} \mathrm{SO}_{4}$ treatments on the chemistry of soil drainage water and pine seedlings in forest soil microcosms. Hydrol. Earth Syst. Sci., 8, 392-391.

Wilkinson, R.J., Reynolds, B., Neal, C., Hill, S., Neal, M. and Harrow, M.L. 1997. Major, Minor and trace element composition of cloud water and rain water at Plynlimon, MidWales. Hydrol. Earth Syst. Sci., 1, 557-570.

Whitehead, P.G., Hill, T.J. and Neal, C., 2004. Impacts of forestry on nitrogen in upland and lowland catchments: a comparison of the River Severn at Plynlimon in Mid Wales and the Bedford Ouse in South-East England using the INCA model. Hydrol. Earth Syst. Sci., 8, 533-544. 